\title{
Militantes de la izquierda latinoamericana en México, 1920-1934. Prácticas políticas, redes y conspiraciones
}

\section{Aimer Granados García}

Departamento de Humanidades

Universidad Autónoma Metropolitana-Unidad Cuajimalpa, México

aimergranados@gmail.com

Sebastián Rivera Mir, Militantes de la izquierda latinoamericana en México, 1920-1934. Prácticas políticas, redes y conspiraciones. México, El Colegio de México/Secretaría de Relaciones Exteriores, 2018. ISBN: 978-607-628-417-9.

En los últimos meses del 2018, sin que investigadores y editoriales se hubieran puesto de acuerdo, aparecieron en México tres libros que, en mucho, coinciden en su línea temática y periodo investigado. En septiembre de ese año salió el libro de Gabriela Pulido Llano y Laura Beatriz Moreno Rodríguez, titulado El asesinato de Julio Antonio Mella: Informes cruzados entre México y Cuba, bajo el sello editorial de la Secretaría de Cultura y del INAH. Durante el mismo mes, vio la luz pública una segunda edición del libro de Ricardo Melgar Bao, Redes e imaginario del exilio en México y América Latina: 1934-1940, editado por el CIALC/UNAM. Y en octubre de 2018 Sebastián Rivera Mir publicó Militantes de la Izquierda latinoamericana en México, 1920-1934. Prácticas políticas, redes y conspiraciones, El Colegio de México/Secretaría de Relaciones Exteriores. Esta coincidencia editorial me parece muy significativa puesto que, desde una perspectiva historiográfica, estas tres investigaciones apuntan a develarnos críticamente el devenir y la dinámica de la militancia latinoamericana de izquierda exiliada en México, un tema realmente poco estudiado. Además, me parece que metodológicamente estas tres investigaciones se ponen en una tesitura de lo transfronterizo. 
Esta perspectiva metodológica es muy importante de destacar, ya que permite hacer lecturas de lo nacional, desde un mirador latinoamericano que enriquece, renueva y, de alguna manera, revisa la historiografía sobre lo nacional. Un segundo elemento coincidente que llama la atención en estos tres libros de reciente aparición es que las historias de exiliados políticos de izquierda latinoamericanos en el México de la posrevolución que ellos estudian y analizan, tienen como uno de los referentes ideológicos y centrales a la Revolución Mexicana. Efectivamente, como ya lo había planteado cierta historiografía sobre la Revolución Mexicana, ésta fue un proceso que operó ideológicamente como un referente a nivel continental. No gratuitamente, muchos militantes de las izquierdas latinoamericanas durante el periodo que estos libros estudian miraron a México como ejemplo revolucionario el cual debía seguirse. Tristán Marof, por ejemplo, uno de los más prestantes miembros de este exilio, de origen boliviano, decía, refiriéndose a la Revolución Mexicana: "Este experimento es excepcional en el continente y debemos reflexionar seriamente" (citado por Rivera Mir, p. 404). Cabe agregar que otros referentes que operaron ideológicamente y con carácter revolucionario en la esfera de la militancia de izquierda latinoamericana fueron la Reforma Universitaria de 1918, así como las condiciones de desigualdad social, intolerancia política e ideológica, autoritarismo y dictadura que vivía América Latina. En suma, México sirvió como país de refugio a un buen contingente de esta militancia de izquierda.

La edición de este estupendo libro que en primer término constituyó una tesis doctoral del Centro de Estudios Históricos de El Colegio de México, en mucho reconstruye críticamente el mundo político, social, cultural e intelectual de los militantes de izquierda latinoamericana exiliados en México. A partir de estos grandes paraguas temáticos Rivera Mir nos adentra en las prácticas políticas, las dinámicas socio-culturales e intelectuales de un amplio grupo de exiliados de la izquierda latinoamericana que, en buena medida, presionados por las 
condiciones dictatoriales o de autoritarismo en sus respectivos países, pero también alimentados por un imaginario colectivo según el cual México era país de Revolución, tuvieron que asilarse en México. Este grupo de exiliados políticos estuvo conformado por representantes de una buena cantidad de países latinoamericanos, destacando el contingente cubano, el venezolano, el peruano, y el centroamericano.

Un asunto notable en este libro es que combina y articula muchas subdisciplinas de la Historia. En primera instancia, y al menos desde la perspectiva de lectura realizada por el que escribe estas notas, este libro es historia política en la medida que estudia muchas dinámicas de las izquierdas latinoamericanas de las décadas de 1920 y 1930. Pero es insistentemente, para bien de la historiografía, una historia política que rompe con cierta tradición al no detenerse única y exclusivamente en las ideas políticas, en las ideologías y lo ideológico, sino que articula muy bien las condiciones de orden social, político y cultural en donde estas ideologías de izquierda fueron enunciadas. En este sentido podríamos afirmar que de una tradicional historia política y de las ideas que especialmente se preguntaba por las ideas, este libro se monta sobre unos ejes que, en términos generales, enfatizan y guardan una línea metodológica que privilegia, sí el estudio de las ideas, pero insertas, pensadas, promovidas, discutidas e impulsadas en la vida intelectual/cultural y política de la militancia de izquierda latinoamericana exiliada en México durante la posrevolución. Al respecto el autor señala: "los lineamientos ideológicos y las prácticas políticas establecieron un diálogo permanente, algo que la historiografía sobre el periodo ha minimizado, tendiendo a concentrarse solamente en el primer aspecto.” (p. 271). Esto, recientemente, al menos en el ámbito latinoamericano, se ha materializado en una historia de las ideas que progresivamente se ha transformado en historia intelectual. Es, en otras palabras, articular las ideas con las prácticas y con sus escenarios de enunciación y discusión. Es, adentrarse, no solamente en el análisis de las Secuencia. E-ISSN 2395-8464 
condiciones políticas que expulsan grupos de población política e ideológicamente no conveniente al "sistema”, sino también estudiar los cálculos políticos y culturales que, en el terreno de las relaciones internacionales y afianzamiento de los procesos revolucionarios, el Estado posrevolucionario mexicano y su dirigencia hacían en función de ser permisivos, aunque no siempre, con estos exiliados. Pero, además, es investigar las prácticas, en sentido amplio, de estos exiliados: editoriales, políticas, de sociabilidad, de solidaridad, de cómo evitar al enemigo o acercarse a él, educativas, culturales, ideológicas, organizativas, comunicativas, etc. De tal cruce de interese entre países expulsores, el país receptor y los móviles de los exiliados, resulta un abigarrado y complejo sistema de superposición de intereses que hacen de este libro una historia muy compleja. En suma, dirá Rivera Mir, “con este trabajo intentamos comprender cuáles fueron los mecanismos y los problemas que enfrentaron los militantes y extranjeros que llegaron a México para continuar con los procesos políticos, tanto personales como colectivos, desde un territorio distante" (p. 14).

Este objetivo general en el libro de Rivera Mir combina entonces estrategias de interpretación que no sólo tienen en cuenta los proyectos políticos y de vida, colectivos e individuales, de los militantes de izquierda migrados hacia México, sino también las condiciones y circunstancias diversas del exilio político. De esta manera, siguiendo el canon establecido por Mario Sznajder, y Luis Roniger en su libro The Politics of Exile in Latin America (2009), Rivera Mir estudia los cuatro niveles establecidos por estos autores en los procesos de migración política: el país expulsor, el país receptor, el propio emigrado y el espacio transnacional. En el entrecruce de estos vectores analíticos el autor logra una interpretación novedosa, renovadora, crítica y revisionista de la historia, no solamente del grupo de militantes de la izquierda latinoamericana exiliados en México durante las décadas de 1920 y 1930, sino también, y en general, de la historia política, intelectual y cultural 
mexicana en perspectiva transfronteriza. En este revisionismo historiográfico el autor que se comenta logra con mucho éxito un estudio muy completo sobre este exilio latinoamericano en México: sus prácticas, sus redes y sus conspiraciones.

Desde otra perspectiva metodológica y crítica, me parece que este libro acierta en una categoría que, a la manera de eje vector, atraviesa buena parte de la argumentación. Me refiero al concepto de "militantes de izquierda”, entendido por el autor no como la adscripción a un partido o ideología determinada y fija, "sino como una cultura política práctica que pretende transformar los regímenes autoritarios latinoamericanos y, al mismo tiempo, cambiar las condiciones sociales de la mayoría de la población, incorporando nuevos actores”(p.14). Desde esta definición, este concepto da la posibilidad al autor de este libro de romper con dos lineamientos tradicionales al momento de estudiar la práctica política: Concebir las adscripciones políticas e ideológicas como si fueran fijas. Para Rivera Mir es un camino errado en la medida que considera, con razón, que, durante el periodo estudiado, "las dinámicas de las adscripciones políticas, [...] no pueden ser comprendidas si no pensamos el problema de la actividad política de la izquierda como algo que está más allá de marcos ideológicos estáticos” (p.15). En segundo lugar, centrarse en el estudio y análisis de figuras intelectuales o ideólogos que casi siempre aparecen como los únicos protagonistas de la historia política e intelectual. Efectivamente, al romper estas ortodoxias historiográficas, Rivera Mir, sin dejarlas de lado, va más allá de adscripciones partidarias e ideológicas fijas y monolíticas, muy frecuentemente expresadas como "militante comunista", "militante trotskista”, "militante marxista", "militante aprista”, etc. Y al romper estas adscripciones partidistas e ideológicas que en cierta historiografía constituyen verdaderas “cárceles historiográficas”, Rivera Mir se abre a una historia intelectual que, articuladamente, también quiere restituir las prácticas políticas, culturales e intelectuales de aquellos militantes "cuyo nivel de inserción dentro de las Secuencia. E-ISSN 2395-8464 
maquinarias partidistas fue más tenue que en el caso de los dirigentes partidistas, pero no por ello menos importante” (p. 14). Es decir, además de figuras tan descollantes para los procesos de las nacientes izquierdas latinoamericanas en las primeras décadas del siglo XX como José Carlos Mariátegui, Augusto César Sandino, Víctor Raúl Haya de la Torre, Julio Meya, y Tristán Marof, entre muchos otros, aparecen los otros militantes, los militantes de segundo orden casi invisibilizados en otras perspectivas de investigación. Según nuestro autor, estos otros militantes no eran "profesionales de la política” o líderes partidistas (p. 16). Más bien eran estudiantes, periodistas, viajeros, profesores, tipógrafos, abogados, escritores, traductores, poetas, impresores, entre otros actores sociales que, en el decir de Rivera Mir, "conformaron la periferia de las organizaciones o sus bases” (p. 32). Pero que en el engranaje de la sobrevivencia y la disputa por el campo político/ideológico, así como del campo cultural/intelectual, fueron muy importantes. De esta manera Rivera Mir amplia el registro de los actores y protagonistas de la historia intelectual a personajes poco conocidos. No obstante, habrá que precisar que estos actores de la historia intelectual y política de este exilio latinoamericano en México no necesariamente aluden a la figura o a una tipificación del intelectual. Aunque no cabe la menor duda que algunos de ellos sí se acercaban en mucho a los perfiles de un intelectual. Por ejemplo, los salvadoreños Pedro Geoffroy Rivas y Carlos M. Flores; los peruanos Carlos Manuel Cox y Esteban Pavletich o el venezolano Rómulo Betancourt, entre muchos otros casos que, sin ser figuras de primer orden, constituyen o hacen parte de una intelectualidad que tradicionalmente ha sido ignorada en otras historias. Pero más precisamente, en la línea de Rivera Mir, eran "militantes” de la izquierda.

El interés que Rivera Mir tiene en incorporar a estos actores que muchas veces en la documentación aparecían bajo el rotulo de “trabajadores intelectuales”, es sistemático, tanto, que armó una especie de anexo biográfico al libro que contiene 192 entradas de biografías Secuencia. E-ISSN 2395-8464 
mínimas a propósito de estos personajes, seguramente eran muchos más, invisibilizados por cierta historiografía. Haber perfilado, consolidado y restituido este catálogo de migrantes y militantes de izquierda en México, a la vez que investigado en sus dinámicas políticas, culturales e intelectuales, permite avanzar en el análisis y la complejidad del fenómeno migratorio de militancia de izquierda en el contexto latinoamericano y más específicamente en el contexto mexicano.

El libro de rivera Mir está articulado en seis capítulos precedidos de una introducción. Finaliza con un epílogo, un anexo de biografías mínimas sobre los principales protagonistas de esta historia y un índice onomástico de mucha utilidad. 